\title{
Efforts to Improve Learning Outcomes with Reward Techniques in Integrative Thematic Learning for Grade I Students of SDN 1 Sawangan, Patikraja District
}

\section{Sulih Ristyani Ayu Saputri}

SD Negeri 1 Sawangan

putriquenamanda24@gmail.com

\section{Article History}

accepted 14/11/2020

\begin{abstract}
The purpose of this study was to improve learning outcomes with reward techniques in integrative thematic learning for grade I SDN 1 Sawangan students. The research carried out was Classroom Action Research (PTK) which was carried out through 3 learning cycles which were preceded by an initial cycle or pre-cycle. Learning steps taken as action or corrective measures include cycle I, cycle II and cycle III to determine the development of students. Each cycle includes planning, implementing actions, observing, and reflecting. In cycle I, students who completed the postest were $28.57 \%$. In cycle II, students who completed the postest were $57.14 \%$. In cycle III, students who completed the postest were $85.71 \%$. These results indicate that the reward technique can improve student learning outcomes, especially in learning the theme of my family, the sub-theme of class I family members at SDN 1 Sawangan, Patikraja District.
\end{abstract}

Keywords: learning outcomes, reward techniques, integrative thematic

\begin{abstract}
Abstrak
Tujuan dari penelitian ini adalah meningkatkan hasil belajar dengan teknik reward dalam pembelajaran tematik integratif pada siswa kelas I SDN 1 Sawangan. Penelitian yang dilakukan adalah Penelitian Tindakan Kelas (PTK) yang dilaksanakan melalui 3 siklus pembelajaran yang didahului siklus awal atau prasiklus. Langkah pembelajaran yang diambil sebagai tindakan atau langkah perbaikan meliputi siklus I, siklus II dan siklus III untuk mengetahui perkembangan peserta didik. Setiap siklus meliputi kegiatan perencanaan, pelaksanaan tindakan, observasi, dan refleksi. Pada siklus I peserta didik yang tuntas dalam postest sebanyak $28,57 \%$. Pada siklus II peserta didik yang tuntas dalam postest sebanyak $57,14 \%$. Pada siklus III peserta didik yang tuntas dalam postest sebanyak $85,71 \%$. Hasil ini menunjukkan teknik reward dapat meningkatkan hasil belajar peserta didik khususnya pada pembelajaran Tema Keluargaku Subtema Anggota Keluargaku kelas I di SDN 1 Sawangan Kecamatan Patikraja.
\end{abstract}

Kata kunci: hasil belajar, teknik reward, tematik integratif

Social, Humanities, and Education Studies (SHEs): Conference Series https://jurnal.uns.ac.id/shes

p-ISSN 2620-9284

e-ISSN 2620-9292 


\section{PENDAHULUAN}

Pendidikan merupakan hal yang tidak dapat dipisahkan dari manusia. Menurut H.A R Tilaar (2002: 29), keberadaan pendidikan tidak terlepas dari keberadaan manusia. Pendidikan terjadi sejak manusia lahir, bahkan sejak berada dalam kandungan sudah terjadi pendidikan hingga akhir hayat. Melalui pendidikan, manusia diharapkan dapat meningkatkan dan mengembangkan seluruh potensi atau bakat alamiahnya sehingga nantinya menjadi manusia yang dapat berdaya guna dan berhasil guna (Achmad Daldiri dalam Dwi Siswoyo, 2007: 1). Hal tersebut senada dengan pengertian pendidikan dalam Undang-Undang RI Nomor 20 Tahun 2003 tentang Sistem Pendidikan Nasional pasal 1 yang menyebutkan bahwa, "Pendidikan adalah usaha sadar dan terencana untuk mewujudkan suasana belajar dan proses pembelajaran agar peserta didik secara aktif mengembangkan potensi dirinya untuk memiliki kekuatan spiritual keagamaan, pengendalian diri, kepribadian, kecerdasan, akhlak mulia, serta keterampilan yang dibutuhkan bagi dirinya, masyarakat dan bangsa."

Berdasarkan pengertian tersebut, maka belajar dan pembelajaran mempunyai kaitan yang erat dalam pendidikan. Menurut Hamzah B. Uno (2003: 78) belajar adalah suatu proses usaha yang dilakukan oleh seseorang untuk memperoleh suatu perubahan tingkah laku yang baru, secara keseluruhan, sebagai hasil pengalamannya sendiri dalam interaksinya dengan lingkungannya.

Perubahan tingkah laku dalam manusia bermacam-macam dan tidak semua perubahan tingkah laku tersebut termasuk dalam kegiatan belajar. Lebih lanjut Sugihartono (2007: 74) menjelaskan perubahan tingkah laku yang terjadi dalam belajar memiliki ciri-ciri perubahan secara sadar, perubahan yang bersifat kontinyu dan fungsional, perubahan bersifat positif dan aktif, perubahan tidak bersifat sementara, perubahan dalam belajar bertujuan atau terarah, dan perubahan mencakup seluruh aspek tingkah laku. Perubahan tingkah laku yang terjadi dalam belajar, antara perubahan tingkah laku satu memiliki hubungan dengan perubahan tingkah laku yang lain.

Pembelajaran menurut Aunurrahman (2010: 34) berperan sebagai sistem yang bertujuan untuk membantu proses belajar siswa yang berisi serangkaian peristiwa yang dirancang dan disusun sedemikian rupa untuk mendukung dan mempengaruhi terjadinya proses belajar siswa yang bersifat internal. Guru memiliki peran penting dalam pembelajaran, karena guru harus merancang dan mempertimbangkan proses belajar siswa dengan melihat situasi dan kondisi yang ada. Pembelajaran harus mengarah pada upaya meningkatkan potensi siswa secara komprehensif serta upaya meningkatkan kegiatan guru dalam mengajar, maka pembelajaran harus dikembangkan sesuai dengan prinsip-prinsip yang benar. Prinsip- prinsip belajar menurut Dimyati dan Mujiono (2013: 42) berkaitan dengan (1) perhatian dan motivasi, (2) keaktifan, (3) keterlibatan langsung, (4) pengulangan, (5) tantangan, (6) balikan dan penguatan, serta (7) perbedaan individual.

Pembelajaran tematik integratif adalah pendekatan pembelajaran yang mengintegrasikan berbagai kompetensi dari berbagai matapelajaran ke dalam berbagai macam tema (Permendikbud, 2013). Adapun ciri-ciri dalam pembelajaran tematik integratif (Trianto, 2011: 163-164) antara lain: (1) berpusat pada anak, (2) memberikan pengalaman langsung, (3) pemisahan antar mata pelajaran tidak nampak, (4) menyajikan konsep dari beberapa mata pelajaran dalam satu PBM, (5) bersifat luwes, dan (6) hasil pembelajaran dapat berkembang sesuai dg minat dan kebutuhan anak.

Hamzah B. Uno (2013: 23) memaparkan motivasi belajar dapat timbul karena faktor intrinsik yang berupa hasrat atau keinginan berhasil dan dorongan kebutuhan belajar, dan harapan akan cita-cita. Sedangkan faktor ekstrinsik adalah adanya penghargaan (reward), lingkungan belajar yang kondusif, dan kegiatan yang menarik. Kedua faktor tersebut dipengaruhi oleh rangsangan tertentu sehingga seseorang 
berkeinginan untuk melakukan aktivitas belajar yang lebih giat dan semangat, sehingga hasil belajar diharapkan dapat meningkat.

Upaya untuk meningkatkan hasil belajar siswa, peneliti menggunakan teknik reward. Dalam teknik reward ini, yang dapat dilakukan guru adalah memberikan stimulus/ rangsangan kepada siswa agar siswa mempunyai keinginan untuk melakukan aktivitas belajar dengan lebih giat dan semangat. Stimulus/ rangsangan yang penulis maksud adalah reward. Menurut Oemar Hamalik (2008: 167) reward atau penghargaan memiliki tiga fungsi penting dalam mengajari anak berperilaku yang disetujui secara sosial. Fungsi yang pertama ialah memiliki nilai pendidikan. Yang kedua, pemberian reward menjadi motivasi bagi anak untuk mengulangi perilaku yang diterima oleh lingkungan atau masyarakat. Melalui reward, anak justru akan lebih termotivasi untuk mengulangi perilaku yang memang diharapkan oleh masyarakat.

Pemberian stimulus/ rangsangan untuk meningkatkan hasil belajar siswa melalui teknik reward, mengacu pada teori belajar behavioristik Skinner, belajar adalah perubahan tingkah laku sebagai akibat dari adanya interaksi antara stimulus dan respon (Hamzah B. Uno, 2013: 13). Dengan kata lain belajar adalah merupakan bentuk perubahan yang dialami siswa dalam hal kemampuannya untuk bertingkah laku dengan cara yang baru sebagai hasil dari interaksi antara stimulus dan respon. Ketika stimulus yang diberikan kepada siswa yang berupa reward ini berhasil, maka respon yang diharapkan akan menumbuhkan motivasi belajar siswa sehingga berdampak pada hasil belajar siswa yang meningkat.

Dari identifikasi masalah maka rumusan masalah penelitian adalah "Apakah penggunaan teknik reward pada Pembelajaran Tematik Integratif dapat meningkatkan hasil belajar pada siswa kelas I SDN 1 Sawangan ?"

Berdasarkan rumusan masalah maka tujuan penelitian ini adalah untuk meningkatkan hasil belajar dengan teknik reward dalam pembelajaran tematik integratif pada siswa kelas I SDN 1 Sawangan.

\section{METODE}

Penelitian ini adalah penelitian tindakan kelas (Classroom Action Research) dengan menerapkan teknik reward. Kegiatan penelitian ini dilaksanakan melalui 3 siklus pembelajaran yang didahului dengan siklus awal atau prasiklus sebagai dasar mengetahui sejauh mana prestasi belajar yang dimiliki oleh peserta didik kelas 1 . Selanjutnya dilakukan langkah perbaikan melalui pembelajaran siklus I, siklus II dan siklus III. Tiap siklus meliputi empat kegiatan, yaitu kegiatan perencanaan, pelaksanaan, observasi, dan refleksi. Penelitian ini dilaksanakan pada siswa kelas I SDN 1 Sawangan tahun ajaran 2020/2021 secara luring. Siklus I dilaksanakan pada tanggal 2 November 2020, Siklus II dilaksanakan pada tanggal 9 November 2020, Siklus III dilaksanakan pada tanggal 16 November 2020. Teknik pengumpulan data dilakukan dengan cara tes, observasi, dokumentasi dan sebagainya. Instrumen yang digunakan dalam penelitian ini berupa Lembar observasi, Lembar tes/evaluasi, lembar penilaian proses dan hasil. Penelitian tindak kelas ini menggunakan metode penelitian deskriptif kuantitatif dan kualitatif. Observasi meliputi observasi keterlibatan siswa dalam pembelajaran, sikap peserta didik dan keterampilan. Untuk hasil belajar menggunakan tes penilaian evaluasi.

\section{HASIL DAN PEMBAHASAN}

Kondisi awal atau prasiklus sebelum diadakan penelitian tindakan kelas siswa kelas I SD Negeri 1 Sawangan tema Keluargaku, Subtema Anggota Keluargaku ketuntusan klasikal sebesar 14,29\%. Hasil belajar siswa menunjukkan dari 7 siswa hanya 1 siswa saja yang tuntas dengan KKM 70, sedangkan $6(85,71 \%)$ siswa belum 
tuntas. Dengan nilai terendah adalah 30 dan nilai tertinggi 70 . Sedangkan rata-rata nilai ketuntasan klasikal hanya 41,43 . Berikut data hasil belajar prasiklus yang disajikan dalam tabel :

Tabel 1. Hasil Belajar Siswa Prasiklus

\begin{tabular}{clc}
\hline No. & \multicolumn{1}{c}{ Pencapaian } & Data PraSiklus \\
\hline 1. & Nilai terendah & 30 \\
\hline 2. & Nilai tertinggi & 70 \\
\hline 3. & Rata-rata & 41,43 \\
\hline 4. & Ketuntasan klasikal & $14,29 \%$ \\
\hline 5. & Ketidaktuntasan & $85,71 \%$ \\
\hline 6. & Siswa tuntas & 1 \\
\hline 7. & Siswa tidak tuntas & 6 \\
\hline
\end{tabular}

Menyadari hal tersebut, guru melakukan refleksi dan mengidentifikasi masalah berdasarkan hasil belajar dari prasiklus. Sehingga dilaksanakan tindakan kelas dalam pembelajaran tematik integratif teknik reward melalui tiga siklus perbaikan.

Pembelajaran pada siklus I yaitu tema keluargaku subtema anggota keluargaku menggunakan teknik reward dengan bantuan media audio visual menggunakan tampilan powerpoint dan video. Reward yang diberikan berupa pujian, tepuk hebat, serta tanda bintang. Pada siklus I hasil observasi menunjukkan bahwa keterampilan guru yang meliputi penugasan materi, sistematika penyajian, penerapan metode, penggunaan media, performance, dan pemberian motivasi menunjukkan kategori Cukup Baik. Pada pengamatan aktivitas siswa yang meliputi keaktifan siswa, perhatian siswa, kedisiplinan, dan penugasan menunjukkan kriteria cukup baik. Berikut ini adalah tabel hasil belajar peserta didik pada siklus I :

Tabel 2. Hasil Belajar siklus I

\begin{tabular}{clc}
\hline No. & \multicolumn{1}{c}{ Pencapaian } & Data Siklus I \\
\hline 1. & Nilai terendah & 40 \\
\hline 2. & Nilai tertinggi & 80 \\
\hline 3. & Rata-rata & 60,00 \\
\hline 4. & Ketuntasan klasikal & $28,57 \%$ \\
\hline 5. & Ketidaktuntasan & $71,43 \%$ \\
\hline 6. & Siswa tuntas & 2 \\
\hline 7. & Siswa tidak tuntas & 5 \\
\hline
\end{tabular}

Berdasarkan tabel di atas, menunjukkan bahwa nilai rata-rata kelas I dalam pembelajaran tema Keluargaku Subtema Anggota Keluargaku, pada muatan pelajaran SBDP, Bahasa indonesia dan PPKn yaitu Lagu Sayang Semuanya, Cara memperkenalkan diri dan anggota keluarga, Teks pancasila dan simbolnya, Penerapan sila pertama pancasila adalah 60,00 dengan nilai terendah 40 dan nilai tertinggi 80 . Sebanyak 2 siswa $(28,57 \%)$ pada siklus I sudah mengalami ketuntasan, sedangkan 5 siswa $(71,43 \%)$ belum tuntas. Penilaian tersebut berdasarkan KKM yang telah ditetapkan sekolah yaitu $\geq 70$.

Berdasarkan hasil observasi siklus I maka perlu diadakan perbaikan pada siklus II, dikarenakan belum mencapai ketuntasan klasikal yang diharapkan.Siklus II yaitu pembelajaran tema keluargaku subtema anggota keluargaku menggunakan teknik reward dengan bantuan media audio visual menggunakan tampilan powerpoint dan video dan media konkret berupa puzzle. Reward yang diberikan berupa pujian, tepuk hebat, tanda bintang, serta hadiah bingkisan. Pada siklus II hasil observasi menunjukkan bahwa keterampilan guru yang meliputi penugasan materi, sistematika penyajian, penerapan metode, penggunaan media, performance, dan pemberian 
motivasi menunjukkan kategori baik. Pada pengamatan aktivitas siswa yang meliputi keaktifan siswa, perhatian siswa, kedisiplinan, dan penugasan menunjukkan kriteria baik. Berikut ini adalah tabel hasil belajar peserta didik pada siklus II :

Tabel 3. Hasil Belajar siklus II

\begin{tabular}{clc}
\hline No. & \multicolumn{1}{c}{ Pencapaian } & Data Siklus II \\
\hline 1. & Nilai terendah & 60 \\
\hline 2. & Nilai tertinggi & 90 \\
\hline 3. & Rata-rata & 68,57 \\
\hline 4. & Ketuntasan klasikal & $57,14 \%$ \\
\hline 5. & Ketidaktuntasan & $42,86 \%$ \\
\hline 6. & Siswa tuntas & 4 \\
\hline 7. & Siswa tidak tuntas & 3 \\
\hline
\end{tabular}

Berdasarkan tabel di atas, menunjukkan bahwa nilai rata-rata kelas I dalam pembelajaran tematik terpadu tema Keluargaku Subtema Anggota Keluargaku, pada muatan pelajaran SBDP, Bahasa indonesia dan PPKn yaitu Lagu Sayang Semuanya, Cara memperkenalkan diri dan anggota keluarga, Teks pancasila dan simbolnya, Penerapan sila pertama pancasila adalah 68,57 dengan nilai terendah 60 dan nilai tertinggi 90 . Sebanyak 4 siswa $(57,14 \%)$ pada siklus II sudah mengalami ketuntasan, sedangkan 3 siswa $(42,86 \%)$ belum tuntas. Persentase ketuntasan klasikalnya meningkat, jika siklus 1 hanya $28,57 \%$ maka pada siklus II menjadi $57,14 \%$. Setelah melakukan refleksi pada siklus II, maka diputuskan untuk melanjutkan pada siklus III. Hal ini dilakukan agar mengetahui sejauh mana penerapan teknik reward dalam pembelajaran dapat meningkatkan hasil belajar siswa secara signifikan. Pada siklus III materi yang diajarkan tema keluargaku subtema anggota keluargaku dengan media audio visual berupa tampilan powerpoint dan video, serta media konkret yang lebih menarik. Peserta didik mengerjakan LKPD berupa permainan puzzle dan menggambar simbol Pancasila. Reward yang diberikan berupa pujian, tepuk hebat, tanda bintang, permen, serta hadiah bingkisan Pada siklus III hasil observasi menunjukkan bahwa keterampilan guru yang meliputi penugasan materi, sistematika penyajian, penerapan metode, penggunaan media, performance, dan pemberian motivasi menunjukkan kategori amat baik. Pada pengamatan aktivitas siswa yang meliputi keaktifan siswa, perhatian siswa, kedisiplinan, dan penugasan menunjukkan kriteria amat baik. Berikut ini adalah tabel hasil belajar peserta didik pada siklus III :

Tabel 4. Hasil Belajar siklus III

\begin{tabular}{clc}
\hline No. & \multicolumn{1}{c}{ Pencapaian } & Data Siklus III \\
\hline 1. & Nilai terendah & 60 \\
\hline 2. & Nilai tertinggi & 100 \\
\hline 3. & Rata-rata & 78,57 \\
\hline 4. & Ketuntasan klasikal & $85,71 \%$ \\
\hline 5. & Ketidaktuntasan & $14,29 \%$ \\
\hline 6. & Siswa tuntas & 6 \\
\hline 7. & Siswa tidak tuntas & 1 \\
\hline
\end{tabular}

Berdasarkan tabel di atas, menunjukkan bahwa nilai rata-rata kelas I dalam pembelajaran tema Keluargaku Subtema Anggota Keluargaku pada muatan pelajaran SBDP, Bahasa indonesia dan PPKn yaitu Lagu Sayang Semuanya, Cara memperkenalkan diri dan anggota keluarga, Teks pancasila dan simbolnya. Penerapan sila pertama pancasila adalah 78,57 dengan nilai terendah 60 dan nilai tertinggi 100 . 
Sebanyak 6 siswa (85,71\%) pada siklus III sudah mengalami ketuntasan, sedangkan 1 siswa $(14,29 \%)$ belum tuntas. Berikut gambar perbandingan rata-rata hasil belajar siswa :

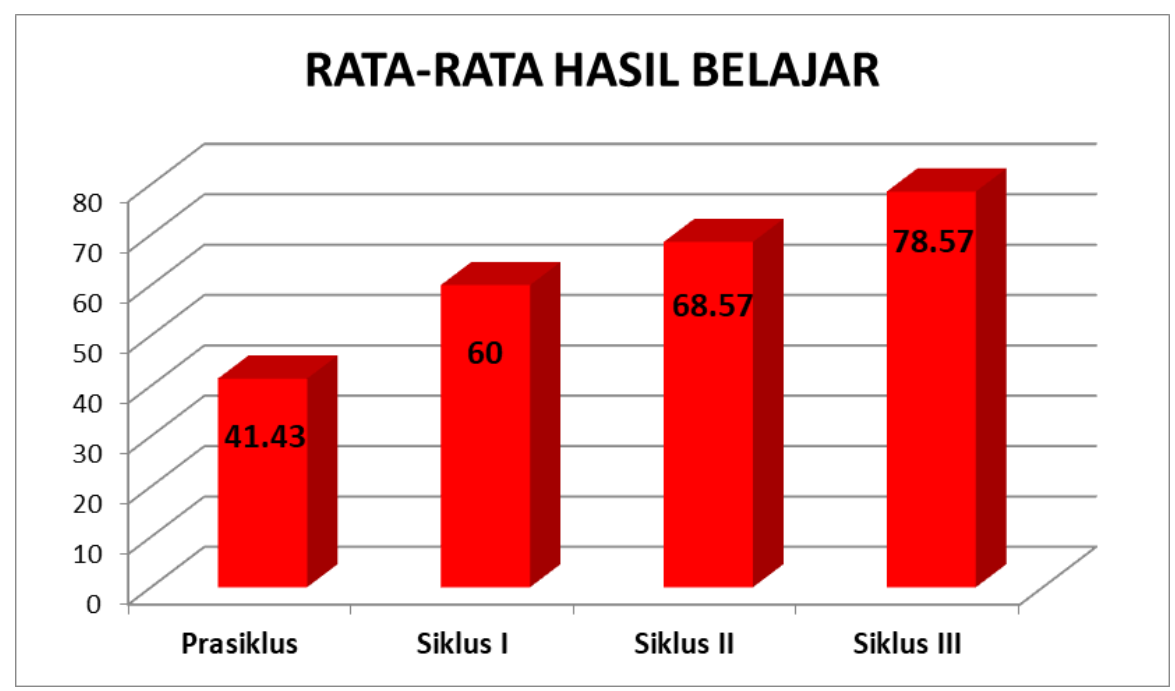

Gambar 1. Perbandingan Rata-Rata Hasil Belajar

Dari tiga siklus yang sudah dilaksanakan selama 3 pertemuan dapat dipastikan bahwa Teknik Reward dapat meningkatkan hasil belajar peserta didik Kelas I di SD Negeri 1 Sawangan. Hal ini sesuai dengan teori yang dikemukakan oleh Ngalim Purwanto (2002: 182), maksud dari pendidik memberikan reward kepada siswa adalah supaya siswa menjadi lebih giat lagi usahanya untuk memperbaiki atau mempertinggi prestasi yang telah dicapainya, dengan kata lain siswa menjadi lebih keras kemauannya untuk belajar lebih baik. reward adalah alat untuk mendidik anak-anak supaya anak dapat merasa senang karena perbuatan atau pekerjaannya mendapat penghargaan. Dengan adanya reward akan menumbuhkan keinginan siswa untuk mengulangi perbuatannya tersebut agar mendapatkan penghargaan. Reward atau ganjaran menurut Ngalim Purwanto (2002: 183) yang dapat diberikan oleh pendidik adalah anggukan kepala, kata-kata pujian, tepuk atau nyanyian, atau hadiah. Hasil penelitian ini juga sesuai dengan penelitian sebelumnya yang dilakukan oleh Ishfi Amalia (2013) yang membuktikan bahwa teknik reward dapat meningkatkan hasil belajar peserta didik.

\section{SIMPULAN}

Hipotesis yang peneliti ajukan pada PTK ini benar-benar terbukti, terlihat dengan adanya peningkatan hasil belajar siswa dalam setiap siklusnya. Peningkatan hasil belajar siswa disebabkan karena antusias siswa dalam pembelajaran melalui penerapan teknik reward. Adanya peningkatan hasil belajar siswa yang ditunjukkan dengan peningkatan hasil evaluasi siswa pada setiap akhir siklusnya. Peningkatan hasil belajar yang signifikan disebabkan karena penerapan teknik reward dalam proses pembelajaran di kelas.

Berdasarkan kerangka teoritis sebagaimana terdapat pada kerangka pikir pada bab II bahwa dengan penerapan teknik reward dapat meningkatkan hasil belajar siswa pada materi tema keluargaku subtema anggota keluargaku pembelajaran 1 bagi siswa kelas I SD Negeri 1 Sawangan Tahun Pelajaran 2020/2021. Dengan demikian, dapat dilihat dengan jelas bahwa kesimpulan secara teoritis sejalan dengan kesimpulan secara empirik. Penerapan teknik reward dalam pembelajaran tematik integratif hendaknya dijadikan salah satu alternatif untuk meningkatkan hasil belajar siswa. 


\section{DAFTAR PUSTAKA}

Aunurrahman. (2010). Belajar dan Pembelajaran. Bandung: Alfabeta.

Dimyanti dan Mujiono. (2013). Belajar dan Pembelajaran. Jakarta: Rineka Cipta.

Dwi Siswoyo. (2007). IImu Pendidikan. Yogyakarta: UNY Press.

Hamzah B. Uno. (2013). Teori Motivasi dan Pengukurannya. Gorontalo: Bumi Aksara. . (2003). Landasan Pembelajaran. Gorontalo: Nurul Janah.

H. A. R Tilaar. (2002). Pendidikan, Kebudayaan dan Masyarakat Madani Indonesia.Bandung: Rosdakarya.

Kemendikbud. (2003). Undang-Undang RI Nomor 20 Tahun 2003 tentang Sistem Pendidikan Nasional. Bandung: Citra Umbara.

Ngalim Purwanto. (2002). IImu Pendidikan Teori dan Praktis. Bandung: Rosdakarya.

Oemar Hamalik. (2008). Proses Belajar Mengajar. Jakarta: Bumi Aksara.

Sugihartono, dkk. (2007). Psikologi Pendidikan. Yogyakarta: UNY Press.

Trianto. (2011). Desain Pengembangan Pembelajaran Tematik bagi Anak Usia Dini TKJ RA dan Anak Usia Kelas Awal SD/ MI. Jakarta: Kencana. 